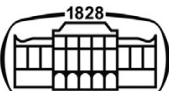

AKADÉMIAI KIADÓ

\title{
The role of sports and well-being programmes in choosing workplaces in the future
}

\author{
RENÁTÓ BALOGH ${ }^{1 *}$ ๑ and ÉVA BÁCSNÉ BÁBA ${ }^{2}$
}

\section{International Review of Applied Sciences and Engineering}

$11(2020) 3,280-286$

DOI:

$10.1556 / 1848.2020 .00148$

(c) 2020 The Author(s)
ORIGINAL RESEARCH PAPER

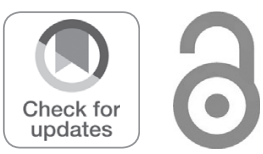

*Correspondig author.

E-mail: balogh.renato@econ.unideb.hu

\author{
${ }^{1}$ Károly Ihrig Doctoral School of Management and Business, University of Debrecen, Böszörményi út \\ 138, 4032 Debrecen, Hungary \\ ${ }^{2}$ Institute of Sport Economics and Management, University of Debrecen, Böszörményi út 138, 4032 \\ Debrecen, Hungary
}

Received: June 25, 2020 • Accepted: July 24, 2020

Published online: October 1, 2020

\section{ABSTRACT}

Due to recent changes in the labour market, recruitment and retaining employees have become more important than ever. Research dealing with the appearance of new generations in the labour market has found that they are less loyal to their employers, have high demands, and the key factors that they consider when choosing a job are salary, career opportunities, working environment, and work-life balance. As numerous studies in recent years have proved the importance of a healthy lifestyle in the context of labour, the question has arisen whether opportunities for sport participation and services supporting the well-being of employees have an influence on young people when they are seeking employment. We carried out an online survey to find out what students of the University of Debrecen think about the issue. The results were in line with the findings of previous studies, that is, young people look for high salaries, good working conditions, work-life balance and career opportunities when choosing a job. However, respondents did not identify sports opportunities and well-being benefits as major factors Yet, we found significant differences between different groups in terms of preference of particular factors, depending on sex, marital status, and whether someone does physical exercises regularly, and whether someone works while attending a university course or not.

\section{KEYWORDS}

labour market, choosing a workplace, health improvement at the workplace, well-being at the workplace

\section{INTRODUCTION}

The financial crisis in 2008 had a negative effect on unemployment rates [1,2] but in recent years the number of unemployed people has decreased. According to KSH (Hungarian Central Statistical Office) data, the unemployment rate has been under $4 \%$ since the first quarter of 2017 in Hungary, which practically means full employment. The Hungarian labour market is characterised more by the lack of workforce now [3], which is a serious problem that negatively impacts our economic development. As a result of the above processes and due to the high level of employee turnover, efficient recruitment and retaining employees have become very important for employers [4], The new (Y and Z) generations' entry into the labour market has made the situation worse. They have high demands in terms of working conditions and salary, but they lack loyalty $[5,6]$. For them, it is natural to change jobs every 2 or 3 years if they can get a better offer [7]. Further, they are driven by success, ambition and self-fulfilment, and are often highly creative and innovative [7]. According to Tari [8], family is much more important than work for new generations, which makes work-life balance a critical factor.

A similar correlation was found by R. Fedor and co-authors $[9,10]$, who examined the employment and family planning plans of women with young children and youngsters. This area has been researched since the '80s [11], and its significance has been growing ever since. Due to their high demands, these young people are hard to retain. This tendency, combined 
with the lifestyle and attitude of the new generation, raises serious concerns. This is what justifies research into how job-seekers choose a workplace and how employers can retain employees.

According to studies, members of the $\mathrm{Y}$ generation choose jobs mainly on the basis of salary and career opportunities [12], while for the $\mathrm{Z}$ generation work-life balance is of utmost importance $[13,14]$. However, it might be useful to consider new factors in studying the area. For instance, innovative and employee-friendly companies have introduced measures and programmes to improve the satisfaction and health of employees. These so-called wellbeing programmes reduce work-related stress, the number of absence days and turnover, and increase employee satisfaction [15]. Deutch and Gergely [16] found that one of the most frequently used methods for coping with stress is sport. Pfau's research findings [1] show that sport is very important for university students. Therefore, it is a valid hypothesis that well-being programmes and sport opportunities may influence job-seekers in choosing an employer.

Besides the above-mentioned reasons, employers should also consider using well-being programmes for financial reasons. According to studies [17, 18], diseases and health conditions related to sedentary lifestyle cause financial loss both for the national economy and for individual companies. According to Ács [19] physical inactivity may lead to HUF 60 billion loss for the national budget. This amount could be reduced by HUF 5.6 billion by increasing the number of people doing some sport by $10 \%$. Well-being programmes can be seen as investments. According to Baicker et al. [20], US companies save USD 3.27 health expense and USD 2.73 absence-related expense with one dollar investment in health improvement. Based on the research findings of Bácsné et al. [21], we can draw the conclusion that Hungarian employers have already realised that it is profitable to invest in their employees' health improvement. Besides satisfying the needs of sport-lovers, it is no less important to motivate physically inactive people to engage in sports. So what role can businesses play in dealing with this issue? In the Eurobarometer [22] survey most people who did not do physical exercise regularly identify lack of time, money, energy or company as reasons. Employers can contribute to the solution of all these problems.

Based on what was said above, it is a valid question whether job-seekers in the future will consider sport and well-being opportunities and benefits when choosing an employer. To justify our research question, we can also refer to previous international [23-25] and Hungarian [26, 27] studies, which all emphasize the importance of healthimprovement in this context.

In the course of our research, we examined the patterns of young people regarding physical activities, and the factors that influence how they choose between employers. Our hypothesis was that sport opportunities and well-being programmes offered by employers have a significant influence on the decision of young people when they have to choose between employers. They may even be among the most important factors, actually.

\section{MATERIAL AND METHODS}

We used a survey for our primary examination. We asked students of the University of Debrecen to complete a questionnaire, which means we did not work with a representative sample. The first part included questions about demographic parameters and sport habits. In the second part we asked respondents about how individual factors would influence their decisions when searching for a job. We listed 25 factors and respondents were asked to evaluate their importance on a 1-5 Likert scale. Some of these factors had been identified by previous studies, others had been defined by us. Finally, we asked students whether sport opportunities offered by employers could influence their decisions in job seeking.

Out of the 416 respondents $45.2 \%$ were men and $54.8 \%$ were women. Due to their student status, $50 \%$ were below 22 years of age, and over $90 \%$ were below 28 at the time of the survey. $39.9 \%$ were single, and $60.1 \%$ were involved in a relationship or married. Many of the respondents lived in

Table 1. Demographic data

\begin{tabular}{|c|c|c|c|}
\hline Variable & Category & Frequency & Ratio (\%) \\
\hline \multirow[t]{2}{*}{ Sex } & Male & 188 & 45.2 \\
\hline & Female & 228 & 54.8 \\
\hline \multirow[t]{4}{*}{ Age } & $18-22$ & 207 & 49.8 \\
\hline & $23-27$ & 172 & 41.3 \\
\hline & $28-32$ & 19 & 4.5 \\
\hline & over 33 & 18 & 5.5 \\
\hline \multirow[t]{2}{*}{ Marital status } & Single & 166 & 39.9 \\
\hline & $\begin{array}{l}\text { Involved in a } \\
\text { relationship or } \\
\text { married }\end{array}$ & 250 & 60.1 \\
\hline \multirow[t]{4}{*}{ Residence } & Budapest & 17 & 4.1 \\
\hline & County centre & 206 & 49.5 \\
\hline & Town & 120 & 28.8 \\
\hline & Village & 73 & 17.5 \\
\hline \multirow[t]{5}{*}{$\begin{array}{l}\text { Financial } \\
\text { situation }\end{array}$} & $\begin{array}{c}\text { Way over the } \\
\text { average }\end{array}$ & 57 & 13.7 \\
\hline & $\begin{array}{c}\text { Somewhat over the } \\
\text { average }\end{array}$ & 109 & 26.2 \\
\hline & Average & 142 & 34.1 \\
\hline & $\begin{array}{c}\text { Somewhat below } \\
\text { average }\end{array}$ & 67 & 16.1 \\
\hline & Way below average & 41 & 9.9 \\
\hline \multirow[t]{4}{*}{$\begin{array}{l}\text { Academic } \\
\text { programme }\end{array}$} & $\begin{array}{c}\text { Advanced } \\
\text { vocational training }\end{array}$ & 30 & 7.2 \\
\hline & $\mathrm{BA} / \mathrm{BSc}$ & 221 & 53.1 \\
\hline & $\mathrm{MA} / \mathrm{MSc}$ & 151 & 36.3 \\
\hline & $\mathrm{PhD}$ & 14 & 3.4 \\
\hline \multirow[t]{2}{*}{ Do you work? } & Yes & 210 & 40.5 \\
\hline & No & 206 & 49.5 \\
\hline \multirow[t]{3}{*}{ Sector } & Public & 134 & 32.2 \\
\hline & Non-profit & 113 & 27.2 \\
\hline & Private & 169 & 40.6 \\
\hline \multirow{2}{*}{$\begin{array}{c}\text { Do you do } \\
\text { physical } \\
\text { exercise? }\end{array}$} & Yes & 282 & 67.8 \\
\hline & No & 134 & 32.2 \\
\hline
\end{tabular}

Source: Our research and edition. 
county centres, about $30 \%$ in towns, $17.5 \%$ in villages, and only a few lived in Budapest. About $75 \%$ indicated that their financial situation was average or better and only $26 \%$ rated their situation below average. We also asked them what programme they were attending at the university. 53.1\% were participating in a BA or BSc programme, $36.3 \%$ in an MA or MSc programme, while $7.2 \%$ were attending advanced vocational programmes and $3.4 \%$ were $\mathrm{PhD}$ students. 50.5\% were working besides pursuing studies. As for their future, about the same percentage indicated that they wanted to work in the private, in the public and in the nonprofit sector. Two thirds of the respondents did some sport activities regularly (at least once or twice a week) (Table 1).

The data collected during the study was processed using the IBM SPSS Statistics 23 software. Basic descriptive statistical indicators were examined and hypothesis testing was carried out, for which, considering the non-normal distribution of the sample, the Mann-Whitney U test was used. This is the non-parameter version of the 2-sample t-test, which allowed us to compare the elements of two groups $[28,29]$. We ran the hypothesis test with different variables. For example, differences between males and females, singles and those involved in a relationship were examined. We also

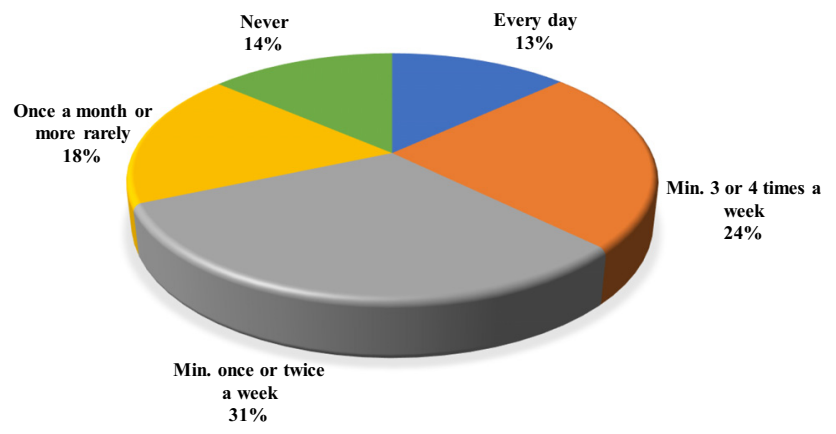

Fig. 1. Distribution of the sample by the frequency of doing physical exercise

(Source: Our own research and editing) examined whether there was a significant difference between respondents who were working and those who were not, and between young people who were living an active lifestyle and those, who were not.

\section{RESULTS}

As we mentioned in the previous section, more than two thirds of the respondents did physical exercise regularly; $13 \%$ every day, $24 \%$ three or four times a week, and most of them $(30.8 \%)$ once or twice a week (this can be linked to the mandatory PE classes introduced at UD). 17.7\%- did some sport once a month, and $13.5 \%$ did not do physical exercise at all (Fig. 1).

We also asked physically inactive students about their reasons. Almost 50\% said they did not have enough time, $16.4 \%$ did not have enough energy, $14.3 \%$ did not have company (Fig. 2). Based on the responses, students who refuse to do physical exercise (or compete) and those with any health problem account only for $10 \%$ of the sample, which means that most of the respondents could be convinced to engage in sports. Employers could solve the rest of the above problems by offering sport opportunities either during working hours or outside of them.

The most important factors that influence job-seekers' decision when choosing a company were good atmosphere (4.61), good conditions and environment (4.58) and salary (4.54). These were followed by career opportunities (4.49) and work-life balance. Fodor [30] and R. Fedor [31] had published similar results earlier. The reputation of the company, corporate culture, benefits and performance-based bonuses were less important for respondents. Interestingly, our findings are in conflict with some previous statements regarding younger generations [8], namely that they prefer teamwork. Our respondents ranked this factor as last but one, which means they valued the opportunity to work independently more. Out of the 25 factors in the list, respondents valued international career opportunities the less,

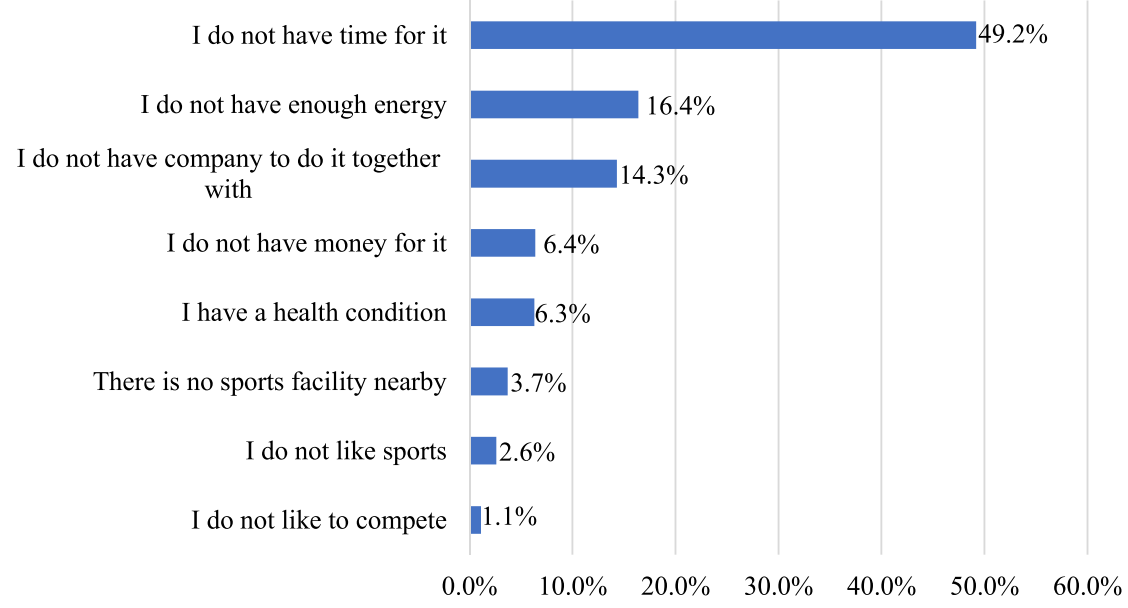

Fig. 2. Why don't you do physical exercises regularly? (Source: Our own research and editing) 


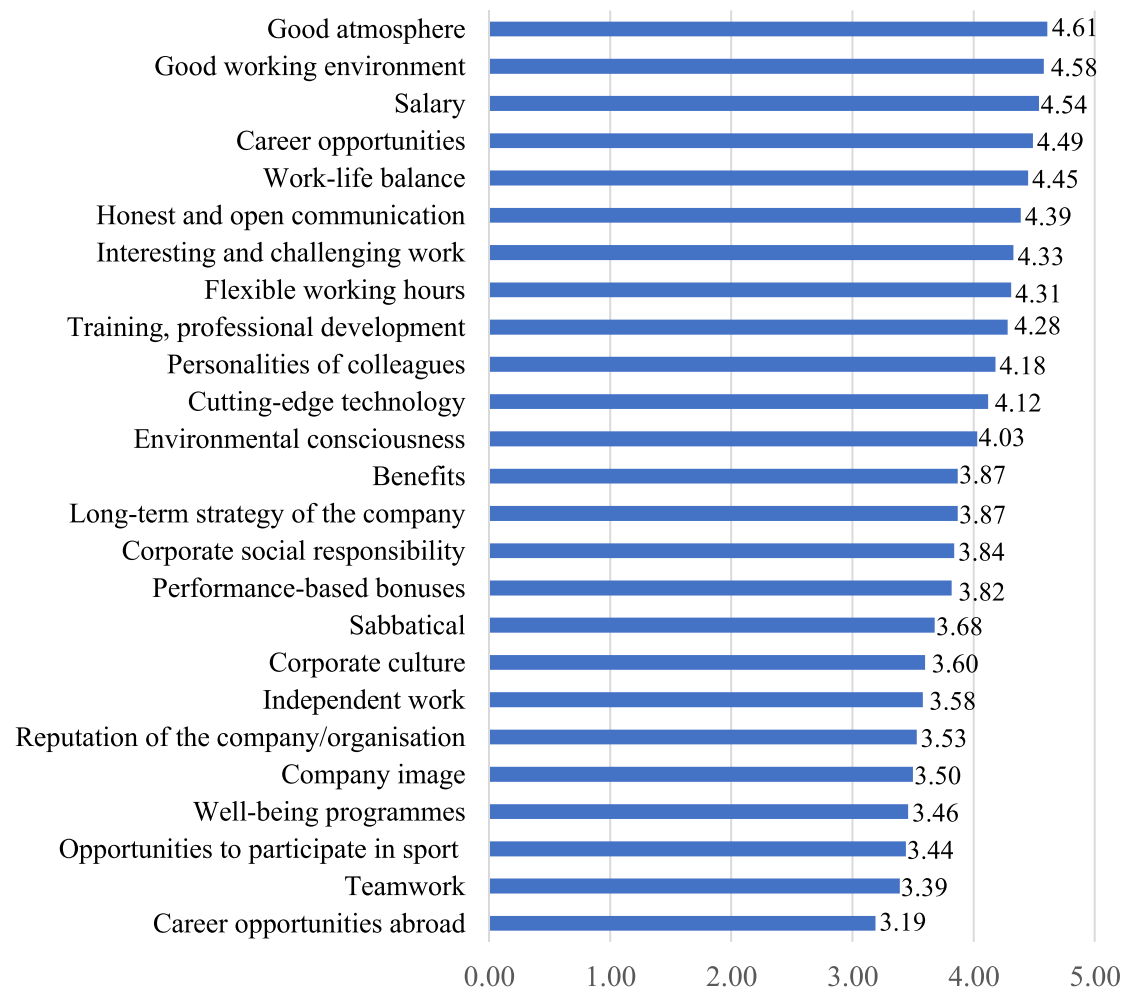

Fig. 3. Preference order of the factors that may influence job-seekers when choosing a company (Source: Our own research and editing)

and sport opportunities (3.44) and recreational or well-being programmes (3.46) were not significant influencing factors either (Fig. 3).

Our hypothesis test revealed significant differences within demographic groups in the case of several variables. For example, between men and women in terms of preference of the following factors: good working environment, environmentally conscious corporate behaviour, the personalities of colleagues, the opportunity for teamwork, honest and open communication on the part of the management, flexible working hours, and corporate social responsibility. All of these factors were more important for women (Table 2).

Also, in most cases, there were significant differences between students who were working and those who were not, with the exception of company reputation, career opportunities, good working environment, training programmes, and the opportunity for independent work. All other factors tended to be preferred by working students (Table 2).

We also found significant differences between the preferences of physically active and inactive students. Teamwork, international career opportunities, flexible working hours, sabbatical, sport opportunities, well-being programmes, and company image were more important for the physically active students, while inactive students found the personalities of colleagues more important (Table 2).

Finally, we examined whether the Mann-Whitney $U$ test revealed significant differences between the preferences of single students and those involved in a relationship or already married in terms of the following factors: other benefits, good working environment, cutting-edge technology, work-life balance, honest and open communication on the part of the management, performance-based bonuses, and well-being programmes (Table 2).

Sports opportunities offered by employers do not really influence the decisions of respondents regarding their workplace preference. Only two measures provided averages close to 4 on the scale: sport card (3.89) and health screening programmes (3.79) (Fig. 4). However, we have to emphasize that the hypothesis testing revealed significant differences between physically active and inactive students in all areas. It means that if the number of physically active job-seekers grows in the future, the demand for sport opportunities offered and financed by employers may grow, and employers should prepare for this development.

\section{CONCLUSIONS}

The new generations' entry into the labour market has changed the scenery in terms of how job-seekers choose between companies, and has therefore posed a new challenge for employers. In line with previous studies, we found that the key factors in choosing a workplace are atmosphere, workplace environment and salary, followed by work-life balance, and career opportunities. However, our findings are in conflict with the results of previous studies, which came to the conclusion that younger generations prefer teamwork to 
Table 2. Results of the hypothesis testing

\begin{tabular}{|c|c|c|c|c|}
\hline Factors & Sex $P$-value & Works $P$-value & Sport $P$-value & Marital status $P$-value \\
\hline $\begin{array}{l}\text { Reputation of the company/ } \\
\text { organisation }\end{array}$ & 0.92 & 0.29 & 0.29 & 0.48 \\
\hline Long-term strategy of the company & 0.26 & $0.01^{\star}$ & 0.24 & 0.18 \\
\hline Salary & 0.28 & $0.03^{*}$ & 0.45 & 0.59 \\
\hline Benefits, bonus & 0.16 & $0.01^{\star}$ & 0.82 & $0.00^{*}$ \\
\hline Career opportunities & 0.52 & 0.06 & 0.82 & 0.12 \\
\hline Interesting and challenging work & 0.37 & $0.00^{\star}$ & 0.47 & 0.36 \\
\hline Good working environment & $0.04^{\star}$ & 0.92 & 0.08 & $0.00^{*}$ \\
\hline $\begin{array}{l}\text { Training programmes, professional } \\
\text { development }\end{array}$ & 0.23 & 0.55 & 0.49 & 0.34 \\
\hline Cutting-edge technology & 0.23 & 0.55 & 0.49 & 0.34 \\
\hline Environmentally conscious behaviour & $0.00^{*}$ & $0.03^{*}$ & 0.32 & 0.24 \\
\hline Work-life balance & $0.00^{*}$ & $0.01^{\star}$ & 0.05 & $0.00^{*}$ \\
\hline Good atmosphere & 0.08 & 0.96 & 0.49 & 0.21 \\
\hline The personalities of colleagues & $0.02^{\star}$ & 0.11 & $0.00^{*}$ & 0.35 \\
\hline Opportunity for teamwork & $0.02^{*}$ & $0.01^{\star}$ & $0.03^{*}$ & 0.06 \\
\hline Opportunity to work independently & 0.34 & 0.24 & 0.60 & 0.06 \\
\hline Career opportunities abroad & 0.94 & $0.04^{*}$ & $0.00^{*}$ & 0.24 \\
\hline $\begin{array}{l}\text { Honest and open communication on } \\
\text { the parte of the management }\end{array}$ & $0.03^{*}$ & $0.00^{*}$ & 0.32 & $0.00^{*}$ \\
\hline Flexible working hours & $0.05^{\star}$ & $0.00^{*}$ & $0.00^{*}$ & 0.12 \\
\hline Sabbatical & 0.54 & $0.00^{*}$ & $0.00^{*}$ & 0.06 \\
\hline Opportunities for physical activities & 0.10 & $0.00^{*}$ & $0.00^{*}$ & 0.39 \\
\hline Social responsibility programmes & $0.01^{\star}$ & $0.02^{*}$ & 0.94 & 0.73 \\
\hline Performance-based bonus & 0.53 & $0.00^{*}$ & 0.40 & $0.05^{*}$ \\
\hline Company image & 0.64 & $0.01^{*}$ & $0.00^{*}$ & 0.49 \\
\hline Corporate culture & 0.54 & $0.00^{*}$ & 0.22 & 0.09 \\
\hline $\begin{array}{l}\text { Well-being programmes offered by the } \\
\text { employer }\end{array}$ & 0.80 & $0.00^{*}$ & $0.04^{\star}$ & $0.00^{*}$ \\
\hline
\end{tabular}

${ }^{\star}$ Significant difference.

Source: Our research and edition

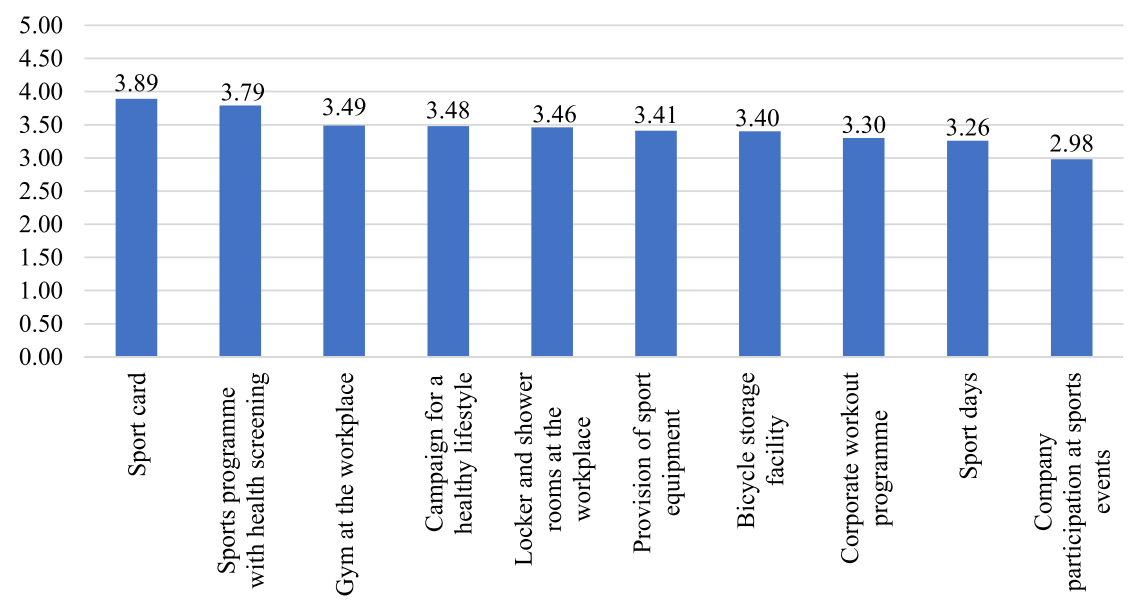

Fig. 4. The effect of measures related to sport opportunities on choosing workplace

(Source: Our research and edition)

independent work. We reached the same conclusion only in the case of young people who do regular physical exercise.

In recent years many researchers have studied health improvement benefits offered by companies and their importance. Yet, our findings do not support the idea that sports opportunities and well-being programmes have a significant effect on choosing an employer. However, we found that sport opportunities and well-being programmes may be important factors for those who do regular physical exercise. It means that employers should pay attention to health programmes, because if the ratio of sporty young people grows, the related programmes and benefits offered by 
companies may become more attractive for job-seekers. For this reason, we suggest that employers carry out a survey to find out what needs their employees have in relation to sport and recreation, for many previous studies have proved that health-improvement programmes may enhance employee satisfaction, which may in turn lead to lower levels of turnover.

\section{ACKNOWLEDGEMENTS}

"The publication was supported by the project nr. EFOP3.6.1-16-2016-0002, entitled Debrecen Venture Catapult Program. The project was co-financed by the EU and the European Social Fund.”

\section{REFERENCES}

[1] I. Szalma, "Hogyan alakult a kétkeresős családok munka és magánélet közötti konfliktus a válság hatására 2004 és 2010 között Európában?," Szociológiai Szemle, vol. 24, no. 1, pp. 102-29, 2014. https://szociologia.hu/dynamic/szalma_102_129old.pdf.

[2] B. Nagy and É. Fodor, “A gazdasági válság hatásai a férfiak és a nők munkaerő-piaci helyzetére Kelet-Közép-Európában,” Szociológiai Szemle, vol. 25, no. 3, pp. 2-22, 2015. https://szociologia. hu/dynamic/nagy_fodor.pdf.

[3] J. Bagó, “A munkaerőhiány a mai Magyarországon,” Opus et Educatio, vol. 5, no. 2, pp. 207-15, 2018. http://opuseteducatio.hu/ index.php/opusHU/article/download/250/423.

[4] B. Chovan, "A munkaerópiac marketing alapú megközelítése," Közép-Európai Közlemények, vol. 10, no. 3, pp. 152-64, 2017. https://ojs.bibl.u-szeged.hu/index.php/vikekkek/article/view/ 12451/12310.

[5] K. Dajnoki and M. Héder, “'Új szelek fújnak' - A HR válasza a globalizáció és a változás kihívásaira," Hadtudomány, vol. 27, e-szám, pp. 84-93, 2017. http://real.mtak.hu/72149/1/dajnoki.pdf.

[6] A. Ferincz and R. Szabó Zs, “Z generáció hatása a munkáltató szervezetekre," Munkaügyi Szemle, vol. 2012, no. 2, pp. 88-93, 2012. http://www.munkaugyiszemle.hu/z-generacio-hatasamunkaltatoi-szervezetekre.

[7] N. Tompa and R. Bakos, “Tehetségmágnesek,” in Tehetségmágnesek, M. Schumann and L. Sartain, Eds., Budapest, HVG Kiadó, 2010, pp. 261-97.

[8] A. Tari, Y generáció - Klinikai pszichológiai jelenségek és társadalomlélektani összefügések az információs korban, Budapest, Jaffa Kiadó, 2010.

[9] R. Fedor Anita and A. Toldi, "Labour market opportunities of women with young children after childbirth," Kontakt, vol. 19, no. 3, pp. 236-43, 2017. https://doi.org/10.1016/j.kontakt.2017.07.003.

[10] R. Fedor Anita, "Családalapítás és gyermekvállalás a fiatalok körében," ACTA MEDICINAE ET SOCIOLOGICA, vol. 7, pp. 20-1, 2018, pp. 11-28, 18. https://doi.org/10.19055/ams.2016.7/ $20-21 / 2$.

[11] B. Nagy, "Létezhet-e munka-magánélet egyensúly vezető állásban?," Szociológiai Szemle, vol. 27, no. 3, pp. 75-103, 2017. https:// szociologia.hu/dynamic/75_103_oldal.pdf.
[12] G. Szabó-Szentgróti, M. Gelencsér, E. Szabó-Szentgróti, and Sz. Berke, "Generációs hatás a munkahelyi konfliktusokban," Vezetéstudomány Budapest Manage. Rev., vol. 50, no. 4, pp. 77-88, 2019. https://doi.org/10.14267/VEZTUD.2019.04.08.

[13] M. Pregnolato, M. H. R. Bussin, and A. F. Schlerchter, "Total rewards that retain: A study of demographic preferences," $S A J$. Human Resource Manage., vol. 15, pp. 1-10, 2017. https://sajhrm. co.za/index.php/sajhrm/article/download/804/1118.

[14] Z Krajcsák, “Az alkalmazotti elkötelezettség relatív fontossága a munka megváltozó világában," Vezetéstudomány Budapest Manage. Rev., vol. 49, no. 2, pp. 38-44, 2018. https://doi.org/10. 14267/VEZTUD.2018.02.04.

[15] B Barna, “A munkahelyi stressz idő vetületei és fóbb forrásai a hadseregben," Hadtudományi Szemle, vol. 11, no. 1, pp. 124-41, 2018. http://epa.oszk.hu/02400/02463/00038/pdf/EPA02463_ hadtudomanyi_szemle_2018_01_124-141.pdf.

[16] Sz. Deutsch, and É. Gergely, “A munkahelyi stressz és elégedettség tényezőinek feltárása egészségügyi dolgozók körében,” Acta Med. Sociol., vol. 6, no. 2, pp. 101-26, 2015. http://epa.oszk.hu/02500/ 02535/00012/pdf/EPA02535_acta_med_2015_17_101-126.pdf.

[17] C. Pfau, "Hallgatói szabadidősport szervezése és jellemzői a felsőoktatásban," TAYLOR Gazdálkodás- és szervezéstudományi folyóirat: A Virtuális Intézet Közép-Európa Kutatására Közleményei, vol. 8, no. 4, pp. 5-16, 2016. https://ojs.bibl.u-szeged. hu/index.php/taylor/article/view/13034/12890.

[18] P. Ács, R. Hécz, D. Paár, and M. Stocker, “A fittség (m)értéke. A fizikai inaktivitás nemzetgazdasági terhei Magyarországon," Közgazdasági Szemle, vol. 58, nos 7-8, pp. 689-708, 2011. http:// www.kszemle.hu/tartalom/cikk.php?id=1259.

[19] A. Müller, I. Balatoni, L. Csernoch, , “Asztmás betegek életminőségének változása komplex rehabilitációs kezelése után,” Orvosi Hetilap, vol. 159, no. 27, pp. 1103-12, 2018. http://real. mtak.hu/81061/1/650.2018.31046.pdf.

[20] A. Müller, G. Ráthonyi, M. Bíró, , "The effect of complex climate therapy on rehabilitaion results of elderly asthmatic and chronic obstructive airways disease (COPD) patients," Eur. J. Integr. Med., vol. 20, no. 6, pp. 106-14, 2018. https://doi.org/10.1016/j.eujim.2018.04.007.

[21] K. Baicker, D. Cutler, and Z. Song, "Workplace wellness programs can generate savings," Health Affairs, vol. 29, no. 2, pp. 59-75, 2010. https://doi.org/10.1377/hlthaff.2009.0626.

[22] É. Bácsné Bába, Gy. Szabados, and T. Madarász, "Munkavállalók fizikai állapot felmérésének tapasztalatai a kkv szektorban," TAYLOR Gazdálkodás- és szervezéstudományi folyóirat: A Virtuális Intézet Közép-Európa Kutatására Közleményei, vol. 9, no. 2, pp. 179-87, 2017. http://www.analecta.hu/index.php/taylor/ article/view/13115/12971.

[23] Special Eurobarometer 472 Report, Sport and physical activity, 2017. https://ec.europa.eu/commfrontoffice/publicopinion/index. cfm/ResultDoc/download/DocumentKy/82432 (Downloaded: 2019. 06. 10.).

[24] H. E. Brown, N. D. Gilson, N. W. Burton, and W. J. Brown, "Does Physical Activity Impact on Presenteeism and Other Indicators of Workplace Well-Being?," Sports Med., vol. 41, no. 3, pp. 249-62, 2011. https://doi.org/10.2165/11539180-000000000-00000.

[25] P. P. Schultz, R. M. Ryan, C. P. Niemiec, N. Legate, and G. C. Williams, "Mindfulness, Work Climate, and Psychological Need Satisfaction in Employee Well-being," Mindfullness, vol. 6, no. 5, pp. 971-85, 2015. https://doi.org/10.1007/s12671-014-0338-7. 
[26] M. Kim, A. C. H. Kim, J. I. Newman, G. R. Ferris, and P. L. Perrewé, "The antecedents and consequences of positive organizational behavior: The role of psychological capital for promoting employee well-being in sport organizations," Sport Management Review, vol. 22, no. 1, pp. 108-25, 2019. https://doi.org/10.1016/j.smr.2018.04.003.

[27] R. A. Fedor, "Labor market participation of women living in the north great plain region," Humán Innovációs Szemle, vols 7-8, nos 1-2, pp. 32-53, 2018.

[28] Á. Szabó and P. Juhász, "A munkahelyi egészségprogramok értékteremtésének mérési lehetőségei," Vezetéstudomány - Budapest Manage. Rev., vol. 50, no. 2, pp. 59-71, 2019. https://doi.org/ 10.14267/VEZTUD.2019.02.05.
[29] P. Takács and G. Fábián, "Egy lokális életminőség index kialakításának lépései,” Acta Med. Sociol., vol. 3, no. 3, pp. 49-68, 2012. https://doi.org/10.19055/ams.2012.3/3/4.

[30] A Vargha, "Szignifikanciatesztek - negyven éve hibás elemzéseket végzek és téveszméket tanítok?," Statisztikai Szemle, vol. 94, no. 4, pp. 445-51, 2016. http://doi.org/10.20311/stat2016. 04.hu445.

[31] M. Fodor, K. Jackel, and O. Nagy, "Employer Branding a Z generáció szemével-Milyen munkahelyre vágynak és milyen szempontok alapján döntenek a munkahelyválasztásról a 'Zk', Vállalkozásfejlesztés a XXI. században, vol. 7, pp. 145-53, 2017. 